\title{
Türk Sosyo-Kültürel Hayatına Fesin Yansıması Bağlamında Antepli Aynî'nin Divanında Fes
}

\author{
NURGÜL ÖZCAN* \\ nurgulozcan34@gmail.com \\ ORCID ID: 0000-0001-5285-6554
}

Öz: Günümüzde Osmanl Devletinin sembollerinden olan fesin çok eski bir tarihi vardır. Türklerin fesle tanışması, 16.yüzyılda Cezayirli denizciler vasıtasıyla olmuştur. Fesin, resmi başlık olarak kabulü, II. Mahmud döneminde, Yeniçeri Ocağı’nın kaldırılması sonrasına rastlar. Fes, Serasker Hüsrev Paşa vesilesiyle Osmanliya getirilmiştir. Sonra da II. Mahmud’un isteğiyle resmi başlik olarak kabul edilmiştir. Fesin halk tarafindan kabul görmesi kolay olmamıştır. Fes konusu sadece siyasetçilerin değil sanat camiasının da gündemine girmiştir. Şairler, fes propagandası yapan şiirler yazmıştır. Dönemin şairlerinden Antepli Aynî de yazdiğı methiyelerle, düşürdüğ̈̈ tarihlerle fes reformuna destek vermiş, bu sebeple padişahın iltifatına mazhar olmuştur. Çalışmamızda; fesin Türk sosyo-kültürel hayatına girişi sonrasında 18. yüzyıl şairlerinden Aynînin divanındaki fesle ilgili unsurlar tespit edilmiş, şairin fes meselesine yaklaşımı ayrıntılı bir şekilde ele alınmıştır. Ayrıca Osmanlı sosyal hayatını derinden et kileyen fes reformunun o dönemde yaşayan bir şairin nazarından edebiyata nasıl yansıdığı incelenmiştir.

Anahtar kelimeler: Fes, Feshane, II. Mahmud, Antepli Aynî.

\section{Giriş}

Edebi metinler üzerinde inceleme yapılırken sadece sanata ve estetiğe ait unsurların ele alınması yeterli değildir. Her metin, edebi özelliklerinin yanı sıra içinde, onu kaleme alan müellifle ve yazıldığı dönemle ilgili önemli ipuçları taşır. Bu bilgiler, dönemin coğrafyası, kültürel özellikleri, sosyal hayatı gibi pek çok konuya ışık tutar. Başka bir alanda yarım kalmış bilgilerin tamamlanmasına katkıda bulunur. Osmanlı Devleti'ndeki geleneğe göre devletin yönetiminde söz sahibi olan her devlet adam1nın kendisine yakın bir şair topluluğunu himaye ettiği düşünülürse, şairin ve şiirin sadece edebiyatla ve sanatla ilgisi olmasının dışında daha fazla bir mahiyete sahip olduğu görülür. Divanların özellikle kaside ve tarihlerle ilgili bölümleri, yazıldıkları dönemin sosyal yaşantısını aksettirmesi açısından fevkalade önemli bilgiler içer-

* Doç. Dr., Türk Dili ve Edebiyatı, Eski Türk Edebiyatı. 
mektedir. Kaside ve tarihler dışındaki bölümlerde de beyitler arasında, devirle ilgili önemli bilgilere ulaşmak mümkündür.

Sosyal bir olayın divanlara yansımasına örnek olarak seçtiğimiz 'Divan Şiirinde Fes' konusu sanat ile toplum ilişkisinin ne kadar güçlü olduğunu göstermektedir. Yaptığımız araştırmalar sonucunda -özellikle 18. yüzyıldan sonra yazılmış divanlarda- fes ile ilgili çok sayıda söyleyişe rastlanmıştır. Konuyla ilgili en dikkat çekici örneklerden biri Sultan II. Mahmud döneminde yaşamış olan Antepli Ayni'dir. Şairin şiirlerinde o dönemin toplum hayatında ciddi hadiselere sebep olan 'fes'e dikkate değer yer ayrilmıştır.

Osmanlı devletinin son yıllarından başlayarak Cumhuriyet dönemindeki Şapka Kanunu'na kadar değişik şekillerde gündeme gelen, Fas şehrinde ortaya çıktığı ve Türkiye'ye daha çok Avrupa'dan ithal edildiği için bu adı taşıyan fes, halen Misır dâhil Kuzey Afrika ülkeleri ve Endonezya ile Malezya başta olmak üzere birçok İslam ülkesinde kullanılmaktadır. "Fesin çok eski bir tarihi vardır. Anadolu'nun mitolojik çağlarında Frikya Kralı Midas’ın icat ettiği "Frikya Külahı” fesin dedesidir denilmektedir. Frikyalılar'dan sonra fesin eski örnekleri olan çeşitli kırmızı külahlar Romalılar, Bizanslılar, Rönesans asırlarında İtalyanlar giymişlerdir.” Kırmızı çuhadan yapılır; tepeye doğru daralan silindir şeklinde olup üstünden sarkan bir püskülü bulunur." ${ }^{2}$ Feste yaygın olarak kullanılan renk kırmızıdır. Kaynaklarda fesin kırmızı renginin kızılcık boyasından elde edildiği söylenir. Kırmızı renginin yanında güvez, siyah, beyaz vb. çeşitli renklerde de fesler üretilmiştir. Nedim bir beytinde beyaz fes giyen bir güzelden bahseder:

Seyret beyaz fesde o zülf-i múanberi

Şeb-bûyu gör ki berk-i semenden kabâsı var (Nedim Divanı G25/3) ${ }^{3}$

Günümüzde daha çok İslam dünyasının bir unsuru olarak ele alınan fes, tarihte hem Müslümanlar hem de Hıristiyanlar tarafından kullanılmıştır. Türklerin fesle tanışması ise 16.yüzyılda Cezayirli denizciler vasıtasıyla olmuştur. Fes kanununa kadar yazılan divanlarda fesin, ağırlıklı olarak Cezayir ve denizcilikle ilgili kavramlarla beraber ele alındığı görülür. Lale Devri şairi Nedim, bir beytinde kırmızı fesli Cezayirli bir afetin kendisini aşk deryasında, 'baştarda eylediği'ni söyler:

Deryâ-yı aşka dün beni baştarda eyledi

Bir dâne al fesli Cezâyirli âfeti (Nedim Divanı G151/4) 4

Türk Dil Kurumu’nun Türkçe sözlüğüne göre ‘baştarda’ kelimesi “Osmanlı donanmasında yer alan kadırga cinsinden bir savaş gemisi türü” olarak açıklanır.

Şeyh Galib, Arap diyarından Cezayirli birinin koltuğunun altında bir fes gördügünü söyleyerek fesi “Cezayir’in püsküllü belası" olarak nitelendirir:

1 Reşat Ekrem Koçu, Türk Giyim Kuşam ve Süslenme Sözlüğü, Ankara: Sümerbank Kültür Yayınları, 1969, s.113. 2 İslam Ansiklopedisi, Hülya Tezcan, İstanbul: Türkiye Diyanet Vakfı Yayınları, 1995, “Fes” maddesi.

3 Nedîm Divanı, haz., Muhsin Macit, Ankara: Atatürk Kültür Merkezi Yayınları, 1997, s.304.

4 Nedìm Divanı, s.370. 
Püsküllü bir belâsını gördüm Cezâyir’in

Zîr-i yedinde milk-i Arabâ feslenir (Şeyh Galib G100/2) ${ }^{5}$

Fes'in resmi başlık olarak kabul edilmesi II. Mahmud döneminde yeniçeri ocağının kaldırılmasından sonra gerçekleşmiştir. "Serasker ve mükerreren Kaptan-1 Derya olan Hüsrev Paşa, fesi memleketimize getirilmesine sebep olmuştur. Kaptan-1 Derya iken gemilerdeki askerlere Tunus'tan getirdiği fesleri giydirmiş, seraskerliğinde de İzmir'de teşkil olunan bir taburun subay ve erlerine fes giydirerek İstanbul'a getirmiştir. Bunların Eski Bâb-1 Seraskeri meydanında (bugünkü İstanbul Üniversitesi meydanı) bu tabura, II. Mahmud huzurunda talimler yaptırmıştı. İşte fesin giyilmesi bu vasıta ile orduya intikal ederek, Tunus'a elli bin fes sipariş edilmiştir." ${ }^{\prime}$ Askerdeki yenilikleri padişahın huzurunda talim ettirirken "nizamiye taburuna giydirmiş olduğu kırmızı fes ordunun serpuşu olarak kabul edilir."7 Yeni kurulan askeri birliğin serpuş meselesini görüşmek üzere Bab-1 Fetva'da bir meclis toplanmıştı. Toplantıda fes’in şer’an, örfen ve aklen boyutları tartışılmış ve bu bağlamda toplumun buna karşı oluşabilecek reaksiyonu değerlendirilerek fes kabul olmuş ve padişah'a arz edilmiştir. ${ }^{8}$ Zamanında yapılan reformlardan dolayı II. Mahmud, Osmanlı modernleşme tarihinin en önemli simalarından birisidir." "Sultan Mahmud, devletin varlığını sürdürebilmesi için, geleneksel Osmanlı yaşayış tarzının da değişmesi kanaatine varmıştır. Bunun sonucunda da giyim, dil, düşünce, hatta yaşayış tarzlarında da değişmeler başlamıştır." ${ }^{10}$ Batılı giysilere fes eklenerek Osmanlı ve İslami bir işaret verilmek istenmişti. Bu değişimin tüm topluma uygulanmasıyla, dinsel, ırksal ve sınıfsal farklılıkların silinerek, "kıyafetin ayrıcalık göstergesi olması engellenmeye çalışılmıştı”. ${ }^{11}$ II. Mahmud, reformlarının kalıcılığını sağlamak ve yeni Osmanlı imajını benimsetmek için kendisi örnek olmuş, lacivert ceketi, püsküllü fesi ve şeritli beyaz pantolonu ile kendi boy resimlerini ve portrelerini yaptırarak bunları devlet dairelerine astırmıştır." ${ }^{12}$ Sivil ve asker tüm devlet memurlarına, İstanbul'da yaşayan erkeklere fes giyme zorunluluğunun getirilmesi üzerine Fransa ve Avusturya'dan da fes ithaline gidilir. ${ }^{13}$ Padişahın, fes giyme mecburiyetini şart koşması Müslüman vatandaşların gayri Müslimler ile aynı statüde görülmesi olarak algılanmış ve bu bakımdan fesin kabul edilmesinde güçlüklerle karşılaşılmıştır. ${ }^{14}$ "II. Mahmud'un askeri giysilerde Avrupa'yı örnek alırken, başlıklarda tam tersine doğuyu örnek alarak fesi tercih etmesi, kılık kıyafetteki bu radikal değişimi biraz olsun yumuşatarak, gelecek

5 Şeyh Gâlîb Dîvânı, haz., Muhsin Kalkışım, Ankara: Akçağ Yayınları, 1994, s.306.

6 Selami Kılıç, "Şapka Meselesi ve Kılık Kiyafet İnkılâbı”, Atatürk Yolu, 16/4 (1995), s.530.

7 İslam Ansiklopedisi, Halil İnalcık, İstanbul: Türkiye Diyanet Vakfı Yayınları, 2002, “Koca Hüsrev Paşa” maddesi. 8 Ahmet Rasim, Osmanlı Tarihi(Seçmeler), haz. İsmet Parmaksızoğlu, İstanbul: MEB Yayınları, 1994, s.120-122.

9 Yunus İnce, "II. Mahmut Dönemi Reformlarının Tebaa Tarafından Algılanışı”, Tarih İncelemeleri Dergisi, XXXII/2 (2017), s.452.

10 Abdülkadir Özcan, "II. Mahmut ve Reformları Hakkında Bazı Gözlemler”, Tarih İncelemeleri Dergisi, 10 (1995), s.13-39.

11 Cevdet Kırpık, “Osmanlı İmparatorluğu’nda Modernleşme Sancıları, Fes-Şapka Çatışması”, Toplumsal Tarih, 162 (2007), s.14-22.

12 Emine Koca, "18.ve 19. Yüzyıl Osmanlı Erkek Modası", Türk İslam Medeniyeti Akademik Araştırmalar Dergisi, 7 (2009), s.63.

13 Hamza Çakır, “Türkçe Basında İlk "Marka” Rekabeti”, Erciyes Üniversitesi Sosyal Bilimler Enstitüsü Dergisi, $1 / 16$ (2004), s.29.

14 Fatma K. Barbarosoğlu, Moda ve Zihniyet, İstanbul: İz Yayıncılık, 2004, s.73. 
tepkilere önlem olarak değerlendirilebilir." ${ }^{15}$ İlk zamanlar halkın tepkisini çeken fes "kıyafet kanunu yürürlüğe girdikten sonra 1925'te yasaklanıncaya kadar bir asırlık bir dönem içinde, kadın erkek herkes ve her kesim tarafından giyilmeye başladı. ${ }^{16}$ Fes, halk arasında kabul gördükten sonra sevilmiş ve hatta Osmanlılığın simgesi haline gelmiştir. ${ }^{17}$

Asırlardır kökleşmiş geleneklerin, toplumda yer edinmiş alışkanlıkların değiştirilmesi Sultan Mahmud'un epey başını ağrıtmış, padişah hem içeriden hem de dişarıdan acımasız eleştirilere maruz kalmıştır. Her siyaset adamı gibi II. Mahmud da icraatlarını destekleyecek, reformlarının toplum tarafından kabul edilmesini kolaylaştıracak taraftarlara ihtiyaç duymaktaydı. O dönemde şiirin medya vazifesini ifa ettiği göz önünde bulundurulduğunda, şairlerin bu meseleyle ilgili şiir yazmaları kaçınılmazdı. Yapılan icraatların toplumda kabul görmesini hızlandıracak vasıtaların başında siyasetten hemen sonra edebiyat gelmekteydi. "Osmanlının son dönemlerinde başta padişahlar olmak üzere yöneticiler, şairlerden bilinçli olarak yararlanmışlar, bu şairler aracılığı ile halkın nabzını tutmuşlardır." ${ }^{18}$ II. Mahmud döneminde yapılan reformların -bilhassa fes meselesinin- toplum nezdinde kabulünü hızlandırmak için kasideler, gazeller yazılmış, tarihler düşürülmüştür. Dönemin şairlerinden Meşhûrî, Bursalı İffet, Diyarbakırlı Osman Nûrî̀ ${ }^{19}$ Handî, Sünbülzâde Vehbî, Muvakkit-zâde Pertev, Lebîb gibi pek çok şair divanlarında fes konusuna yer vermiştir. Fes meselesi divan şairlerinin dışında Aşıı Şem’î, Erzurumlu Emrah, Dertli, Sümmânî, Bayburtlu Zihnî gibi halk edebiyatı şairleri tarafından da işlenmiştir. "Dertli’nin fesi öven bir şiir söylediğini bu yüzden Çağa ayanlığı ile ödüllendirildiğini biliyoruz." ${ }^{20}$

Dönemin divan şairlerinden Antepli Aynî de tıpkı Dertli gibi yazdığı methiyelerle, düşürdüğü tarihlerle fes reformuna -dikkat çekici bir şekilde- destek vermiştir. Aynî, Divanı'nda fesin özelliklerinin işlendiği 'fes' redifli dört gazeli bulunmaktadır. Bunun dışında eserin değişik yerlerinde aralarda fesle ilgili beyitler vardır. Divanın 'Tarihler' bölümünde Feshâne’nin kuruluşu ile ilgili bir tarih düşürülmüştür.

\section{Antepli Ayni Kimdir?}

Antepli Aynî, 1180 yılında Antep’te dünyaya gelmiştir. ${ }^{21}$ Yirmili yaşlarında İstanbul’a gelen şair, yarım kalan tahsiline İstanbul'da devam etmiştir. "Sultan Ahmed medresesinde eğitim görmüştür. ${ }^{22}$ Arif Hikmet, onun Dürrizade Mehmed Arif Efendi 'nin ikinci defa şeyhülislam oluşuna düşürdüğü tarih dolayısıyla mülazemete nail olduğu

15 Emine Koca, “Osmanlıda Yapılan Kılık Kıyafete İlişkin Reformların Erkek Giysilerinin Biçimsel Özelliklerine Etkileri”, 20th CIÉPO Symposium New Trends in Ottoman Studies, (2012 Haziran), s.3. (erişim 16.03.2019)

16 Nihat Öztoprak, "Divan Şiirinde Giyim Kuşam Üzerine Bir Deneme”, Divan Edebiyatı Araştırmaları Dergisi, 4 (2010), s.141.

17 Nihangül Daştan, “Türk Halk Şiirinde Bir Propaganda Aracı Olarak Fes Şiirleri”, Akademi Sosyal Bilimler Dergisi, 5/15 (2018), s.47.

18 Hüseyin Özcan, “Türk Halk Şiirinde Sosyal Hayat Bağlamında Aşık Dertli’nin Fes Redifli Şiiri”, Uluslararası Sosyal Araştırmalar Dergisi, 7/33 (2014), s.239.

19 Gülay Durmaz, "Püsküllü Bela: Diyarbakırlı Osman Nûrî Paşa Divanı’nda Fes”, Uludağ Üniversitesi FenEdebiyat Fakültesi Sosyal Bilimler Dergisi, 15/26 (2014), s.201-213.

20 Şerafettin Turan, Türk Kültür Tarihi, İstanbul: Bilgi Yayınevi, 1994, s.217.

21 Antepli Aynî Divanı, haz., Mehmet Arslan, İstanbul: Kitabevi, 2004, s.1.

22 Antepli Aynî Divanı, s.2. 
bilgisini verir. Nitekim Dürrü’n -Nizam'da da yedi ylllı medrese tahsilinden sonra 1210 'da (1795) evlenip aynı yıl mülazım olduğu, üç yıl sonra ise kadılığa geçtiği ve on beş yıl kadı olarak hizmet ettiği kayıtlıdır. ${ }^{23}$ Şair, daha sonra Sultan Mahmud tarafından Bâbıâli Arapça ve Farsça hocalığına getirilir. Yazdığı kasideler ve dönemde gerçekleşen hadiselere düşürdügü tarihlerle padişahın iltifatına mazhar olur. "Hatta 1251 'de bu kasidelerden birine ve hizmetlerine mükâfeten Aynî, Sultan Mahmud tarafından ihdas edilen fakat kendinden sonraki padişah tarafından 1267 tarihinde kaldırılan ve ilk Osmanlı silahşörlük payesi olan bir mücevher nişân (Nişân-1 iftihâr) ile taltif edilerek "Mümeyyizü'ş-Şu'arâ" olarak tayin edilmiştir. ${ }^{24}$ Yetmiş bir yaşında İstanbul'da vefat eden Antepli Aynînin kabri Galata Mevlevihane'sindedir.

Aynî, klasik Türk edebiyatı içinde birinci sınıf şair olarak değerlendirilmese de padişah tarafından "Mümeyyizü’ş-Şu'arâ” olarak iltifat görmesi onun; döneminde tanınmış bir şair olduğunun delilidir. Klasik Türk edebiyatında Antepli Aynînin tarih düşürme alanında tartışılmaz bir yeri vardır. "Antepli Aynî, divanında yer alan 522 tarih manzumesi ile bu türün en önde gelen isimlerinden biridir. Yaklaşık 50 yıla varan bir zaman dilimini içine alan tarih manzumeleri birbirinden değişik konularda söylenmiş olmasıyla dikkat çekmektedir." ${ }^{25}$ Bu durum şairin, dışa dönük bir karaktere sahip olduğunu ve dönemindeki sosyal olaylarla ciddi bir şekilde ilgilendiğini göstermektedir.

Aynî, divanında döneminde gerçekleşen fes reformuna, şiirleriyle açıktan destek vermiş, düşürdüğü tarihler ve fes redifli dört gazeliyle bu konuda dönemin padişahının yanında yer aldığını net bir şekilde göstermiştir.

\section{Antepli Aynî Divanı’nda Fes}

Antepli Aynî, her biri yedi beyit olan fes redifli dört gazelinde; 'fes'i edebi açıdan ele almasının yanı sıra 19. yüzyılda kullanılan fesin şekli, çeşitleri ve renkleri ile ilgili önemli detaylar aktarmıştır. Zaman zaman sosyal hayat içinde fesle ilgili vuku bulan hadiselere yorumlar yapmış, gah fes inkılabını destekleyen gah aleyhtarlarını eleştiren beyitler kaleme almıştır. "Bazı beyitleri estetik amaçlı olup şairin yaptığı benzetme sanatları yönünden dikkat çekicidir. Örneğin beyitlerin birinde, başı ve saçları koruması bakımından fesi, ser-asese yani gece bekçilerinin bekçi başına ya da sevgilinin perçemini Hüma'ya fesi ise onu koruyan renkli kuş yuvasına benzettiği bazı beyitler teşbih açısından alışılmamış benzetmelerdir." ${ }^{26}$ Çalışmamızın bu bölümünde Aynî Divanı'ndaki fesle ilgili detaylar aktarılacak, divanda fesle ilgili tespit edilen unsurlar maddeler halinde tasnif edilip ayrıntılı bir inceleme yapılacaktır.

\section{Sade Fes}

'Sade fes’ o dönemde kullanılan bir fes çeşididir. "Fesin halk arasında benimsenmeye

23 İslam Ansiklopedisi, İsmail Ünver, İstanbul: Türkiye Diyanet Vakfı Yayınları, 1991, “Aynî, Ayıntablı” maddesi. 24 Antepli Aynî Divanı, s.3.

25 Şener Demirel, “Antepli Aynî Divanı’ndaki Tarih Manzumeleri Üzerine Bir İnceleme”, Turkish Studies International Periodical Forthe Languages, Literature and History of Turkishor Turkic, 3/4 (2008), s.375.

26 Mine Mengi, "Fes ya da Püsküllü Bela ve Şiir”, Prof. Dr. Mehmet Özmen Armağanı, 2014, s.235. 
başlamasıyla sivillerin devlet görevlilerinden ayırt edilebilmeleri için "dalfes" (sade, yalın fes) giymeleri, yani etrafına bir şey sarmamaları istenmişti; yalnız ulema efendiler beyaz tülbent sarabileceklerdi. Halkın dalfes giymemekte israr etmesi üzerine esnaf takımının yemeni, çember, ağabani, yazma, tülbent gibi şeyler sarmalarına izin verildi ve bundan sonra fes süratle yayıld.". ${ }^{27}$ Aynî Divanı’nda 'sade fes' kavramı iki yerde geçmektedir. Şair, sade fesle ilgili ilk beyitte, Osmanlı Devleti’nde on beşinci yüzyıldan beri kullanılan sarık ile fesi karşılaştırır "sarığı bilmem ama başa giyilen fes, insanın gamını gideriyor." diyerek fese destek verdiğini hissettirir. Dünyayı bir tekkeye benzeten şair, dünya tekkesinde başka bir şeye ihtiyaç olmadığını, tecrit ehli için bir sade fesin yeterli olacağını söyler:

Câme vü destâr bilmem fark-1 gam-fersâda fes

Ehl-i tecrîde yeter bu tekyede bir sâde fes (G95/1)

Aşağıdaki beyitte, o dönemdeki bir askerin giydiği kıyafetlerin tasviri yapılmaktadır. $\mathrm{Bu}$ beyit dönemin askerî kıyafetlerini göstermesi açısından önemlidir. Beyte göre, askerin elinde sîmîn tâziyâne, belinde altın işlemeli bir kılıç, üzerinde gül-pembe renkli bir elbise, başında sade fes vardır. 'Tâziyâne' lugatte, "Döğen, kamçı, kırbaç"28 anlamına gelir. Askerin belindeki kamçı gümüş işlemelidir. 'Hırvânî̉ ise düz yakalı önü ilikli özel günlerde giyilen bir tören elbisesidir. Beyitte, tasvir edilen askerin k1yafetini tamamlayan en önemli aksesuar başa giydiği 'sade fes'tir:

Elde sîmîn tâziyâne belde tîg-i zer-nişân

Arkada gül-penbe hırvânî serinde sâde fes (G97/3)

\section{Fes/Asker}

II. Mahmud döneminin en büyük hadiselerinden biri şüphesiz 'Vak’a-i Hayriyye' olarak adlandırılan Yeniçeri Ocağı’nın kapatılmasıdır. "Beş yüz yıla yakın varlığını sürdürmüş olan Yeniçeri Ocağı, Osmanlı İmparatorluğu’nun sosyal ve ekonomik gidişinin bir sonucu olarak da askerlik hizmetlerini yerine getiremeyen, ücret almakla yetinen kişiler tarafından doldurularak, devlete yük olmasının yanında, başkentte zaman zaman isyanlar çıkarmaları, idarecileri bu ocağı kaldırmaya sevk etmiştir." ${ }^{29}$ Yeniçeri ocağının yerine kurulan orduya 'Asâkir-i Mansûre-i Muhammediyye' adı verilmiştir. Kurulan yeni ordunun teşkilatında önemli değişikler yapılmış, batılılaşma ile ilgili reformlar önce burada uygulanmıştır.

Aynî, divanında kurulan yeni orduya mensup bir askeri, ayrıntılı bir şekilde tasvir eder. Divanda, fes redifli 97 no'lu gazel "fes-asker" münasebetini göstermesi açısından çok önemlidir. Gazelin tamamında Asâkir-i Mansûre-i Muhammediyye mensubu olan bir askerin maddi-manevi özellikleri resmedilir. Tasvir edilen askerin yaşı on beştir. II: Mahmud döneminde Yeniçeriliğin kaldırılması sonrası duyulan asker ihtiyacını karşılamak üzere, Asâkir-i Mansûre-i Muhammediyye Nizamnamesinde,

27 İslam Ansiklopedisi, "Fes" maddesi, s.416.

28 Mertol Tulum, 17. Yüzyll Türkçesi ve Söz Varlı̆ğ. Ankara: Türk Dil Kurumu Yayınları, 2011, s.1713.

29 Hamiyet Sezer, "Yeniçeri Ocağı’nın Kaldırılı̧̧ının Taşraya Yansıması 1826-1827", Ankara Üniversitesi Dil ve Tarih-Coğrafya Fakültesi Tarih Bölümü Tarih Araştırmaları Dergisi, 19/30 (1997), s.229. 
“asker olarak alınacakların "kim idüğü belirsiz aylak kimseler" ve "muhtedîler” d1şında; on beş ile otuz yaşları arasında, fiziksel olarak elverişli olanlardan seçileceği ifade edilmiştir" ${ }^{30}$ Beyitte tasvir edilen askerin rütbesi yüzbaşıdır. Bunun dışında k1yafeti, hali-tavrı detaylı olarak verilmiştir:

On beşinde böyle bir yüzbaşı gelmez kışlaya

Geyse de her heftede bin nev-cüvân dünyâda fes (G97/2)

Elde sîmîn tâziyâne belde tîg-i zer-nişân

Arkada gül-penbe hırvânî serinde sâde fes (G97/3)

Başka bir beyitte ise; yeni ordunun askerlerine kutsallık atfedilmiştir. Şair, bu askerleri, ahir zamanda Hz. Peygamber'in soyundan geleceğine inanılan Mehdî̀nin ordusunun askerlerine benzetir. Fes de; Hz. İsa’nın nüzul edeceği dönemin övünç kaynağıdır:

Fark-1 cünd-i mehdî-i âl-i Resûl'i zeyn idüp

Fahr ider vakt-i nüzûl-i Hz.İsâda fes (G95/2)

Fes, İslam ordusunun hakimiyeti için 'Açıkbaş ve Kızıl Elma’ya' dek imdada yetişen bir kurtarıcıcıya benzetilir Şair, fesi zafere giden yolda maddi ve manevi olmak üzere iki önemli temele dayandırır. Manevi olarak seçilen isim 'Açıkbaş'tır. Bilindiği üzere Anadolu'nun; Samsun, Diyarbakır, Kastamonu gibi çeşitli yerlerinde bu isimle anılan evliya türbeleri vardır. Bunlardan en meşhuru; "Tokat civarında Selçuklu'dan günümüze yüzyıllar boyu fonksiyonel olarak ayakta kalmış Şeyh Bektut ve Açıkbaş Mustafa Efendi'nin kabirlerinin bulunduğu Açıkbaş Dergâh ${ }^{31}$ dır. Açıbbaş’n başka bir anlamı da kaynaklarda şöyle geçer: “Açıkbaş yahut 'Başıaçık' kavim adıdır. Gerek Osmanlı gerek İran kaynaklarında, sırf başın açıklığı yüzünden adlandırılan bu kavim İmeritiya'da yaşayan Gürcü tayfasından İmeretler'e verilmiş etnonimdir." ${ }^{32}$ Şairin tercih ettiği ikinci kelime ise 'Kızıl Elma'dır. Kızıl Elma, Türkler için cihan hakimiyetinin sembolüdür. ${ }^{33}$ Kızıl Elma'yla daha çok batı yurtlarının fethi kastedilirdi. Aynî, fesi; manasını Açıkbaş ve Kızıl Elma'dan alan cengaver bir kurtarıcıya benzetir. Beyitte dikkat çeken bir başka husus da birinci ve ikinci beyit arasındaki anlam ilişkisidir. Beytin arka planında asker kıyafetlerinin renklerine işaret edilmektedir. Açıkbaş kelimesi, yeşil rengi, dolayısıyla askerî kıyafeti, Kızıl Elma da kırmızıyı yani askerin yeni başlığı olan fesi çağrıştırmaktadır. Şair; 'Açıkbaş' ile doğuda Kafkasya'yı, Kızıl Elma ile de batı bölgelerini kastetmişti

Açıkbaş u Kızıl Elma’ya dek tenfîz ider hükmin

Cünûd-1 ehl-i İslâm’a bütün imdâd-resdir fes (G96/4)

30 Ahmet Yaramış, “Osmanlı Ordusunda Çocuk Askerler Meselesi (Talimhane-i Sıbyan)”,Afyon Kocatepe Üniversitesi, Sosyal Bilimler Dergisi, 8 (2006), s.54.

31 Hasan Demirtaş, "Arşiv Belgeleri Işı̆̆ı̆nda Şeyh Meknun (Bektut)/Açıkbaş Zaviyesi ve Türbesi”, (erişim 16.03.2019), https://docplayer.biz.tr/53587617-Tokat-tarihi-ve-kulturu-sempozyumu.html s.496.

32 Ahmet Caferoğlu, “Türk Onomastiğinda Başlık Yahut Serpûş̧, Sekizinci Türk Dil Kurultayı Bildirileri, (erişim 16.03.2019), http://katalogtarama.cekulvakfi.org.tr/resimler /3/4/1430/ab 00000062 pdf.

33 Fatih Özdemir, "Kızıl Elma’yı Arayan Üç Yazar: Ömer Seyfettin, Ziya Gökalp, Ragıp Şevki Yeşim”, Turkish Studies International Periodical For The Languages, Literature And History Of Turkish Or Turkic, 3/5,503 (2008), s.504. 


\section{Fes/Âşiyân, Kafes}

Fes-âşiyân (kuş yuvası) benzetmesi daha önce yaygın olarak kullanılmamış bir benzetmedir. Bu benzetme bize Fuzûlînnin "Âşiyân-1 mürg-i dil zülf-i perişânundadur" mısraını hatırlatsa da burada farklı kullanılmıştır. Aşağıdaki beyitte perçem hümâ kuşuna fes de şekli ve püskülü münasebetiyle bu kuşu muhafaza eden renkli bir âşiyâna (kuş yuvasına), benzer bir beyitte de kafese benzetilmiştir:

Kimin başında devlet var ise matlûb ider 'Aynî

Hümâ-yı perçem-i dil-dâra rengîn âşiyândır fes (G98/7)

Ser-â-ser cevher-i ikbâl ile tarsî 'alâyıkdur

Hümâ-yı perçeme püsküllü rengîn bir kafesdir fes (G96/2)

\section{Fes/Çiçek}

Fes-çiçek ilişkisi, şairler tarafından eskiden beri yaygın olarak tercih edilen kullanışlardandır. Fesleğen ile fesin bir arada kullanılmasına, diğer şairler de rağbet etmiştir. $\mathrm{Bu}$ iki kelime arasında ses benzerliğinin bulunması şiirin ahengine katkı sağlar. Fesleğenin tercih edilmesinin başka bir sebebi de güzel kokulu bir bitki olmasıdır. Fesle birlikte kullanılan ikinci çiçek, yine güzel kokusu ve şekli münasebetiyle sümbüldür. Sümbül, aynı zamanda fesin mavi renkli püskülünü çağrıştırmaktadır. Konuyla ilgili olarak ele alınan diğer çiçekler ise; lale ve erguvandır. Fes ile lale hem şekil hem renk, erguvan ise sadece renk itibariyle tercih edilmiştir:

Giyinmiş al yeşil gördüm o şûhı feslegenlikde

Bezîr-i berg-i sünbül lâle yâhud ergavândır fes (G98/2)

\section{Fes/Hazine}

Dikkat çekici benzetmelerden birisi de fesin hazineye benzetilmesidir. Şairler şiirlerinde tarih boyunca tarihi-efsanevi şahsiyetlerin sahip olduğu meşhur hazinelere telmihte bulunarak hazine konusunu değişik açlardan ele almışlardır. Aynî, fesi Şâyegân Hazinesi’ne; perçemi de bu hazineyi bekleyen tılsımlı bir ejdere benzeterek hazine ile ilgili kullanışlara bir yenisini eklemiştir. 'Genc-i Şâyegân' diğer bir söyleyişle 'Genc-i Bâd-âverde’ Hüsrev'in hazinesine verilen addır. "İran hükümdarlarından Hüsrev, Rum Kayseri üzerine harp açıp yürüyünce Kayser, hazineleri gemilere yükletip sarp adalara göndermişti. Fakat rüzgâr gemileri Hüsrev'in sahillerine attığından hazineler zapt olmuş ve adına genc-i bâd-âver denilmiştir." ${ }^{34}$ Aynîye göre fesin bir mahremiyeti vardır. O, perçem denilen tılsımlı ejderin önünde nöbet beklediği Şâyegân Hazinesi'dir. Ne sihir ile başkalarına açılır ne de büyü ile:

Açılmaz sihr ile efsûn ile bir dürlü ağyâra

Mutalsam ejder-i perçemle genc-i Şâyegân'dır fes (G98/6)

\section{Fes/lşık}

Aynîye göre fes öyle rastgele bir eşya değildir. Fes, kendisini giymeyi kabul etmeyen

34 Ahmet Talat Onay, Türk Edebiyatında Mazmunlar, haz. Cemal Kurnaz, Ankara: Akçă̆ Yayınları, 1993, s.174. 
kaba softayı Firavun'a, softanın fitneci, pis, habis nefsini de ejderhaya çevirir. Fes giyenlerde ise aynı Hz. Musa misali şimşek gibi -harikulade- bir nur tecelli eder. Şair beyitte, Musa-Firavun kıssasına telmihte bulunarak fes giyenleri yüceltir, giymeyi reddedenleri ise açık bir dille tenkit eder:

Sûfîyi Fir’avn ider nefs-i habîsin ejdehâ

Berk urup nûr-1 tecellî dil-berim Musâ’ da fes (G95/3)

Başka bir beyitte mübalağa sanatıyla fes adeta göklere çıkarılmıştır. Aynî, muhataplarına “Bu fes öyle bir şeydir ki ona atlas göklerinde 'kerrûbiyân’ yani "Allah’a derece itibariyle yakın olan melekler" 35 dokunmuştur. Fes, aydınlığını güneşin (nurundan) ışı̆̆ından, almaktadır.' der. Beyitteki 'târ' kelimesi üzerinde özellikle durmak gerekir. Çünkü târ kelimesi tam da fes için seçilmiş kelimedir. Bu kelimenin çeşitli anlamları vardır. Kelimenin 'tepe, iplik, saç teli' anlamları konu ile doğrudan ilgilidir. Konuyla ilgili klasik Türk şiirinde sık rastlanan ve genellikle birlikte kullanılan başka iki kelime de 'târ u pûd' dur. 'Târ u pûd' lugatte; arış ile argaç olarak geçer. ${ }^{36}$ Derleme Sözlüğünde arış: Dokuma tezgahlarında uzunluğuna atılan ip, boy ipliği, ${ }^{37}$ argaç ise: Dokumalarda çözgü üzerine enliliğine atılan ip ${ }^{38}$ olarak açıklanır. Beyit bu bilgiler ışı̆̆ında şaire göre fesin çözgü ve atkısı güneş 1şı̆̆ındandır:

Anı kerrûbiyân nesceylemişdir çarh-1 atlasda

Şuâ-1 şemsdendir târ u bûdı böyle fesdir fes (G96/6)

Hilal kaşlar üzerinde duran fes, güzelliğiyle ve saçtığı 1şıkla göz kamaştırır. Fesi giyen güzel parmakla gösterilecek kadar farklı bir güzelliğe sahiptir:

Hilâl-i ebruvân üzre müşârün-bi'l-benândır fes

Bu tâb-1 reng ile pertev-fürûz-ı hüsn ü ândır fes (G98/1)

\section{Fes/Kâkül}

Fes ve kâkül, klasik Türk edebiyatı şairlerinin yaygın olarak birlikte kullanmayı tercih ettikleri iki kelimedir.

Çıkdı başdan perçemi sevdâlanup kâkül gibi

Ol güle bir hayli reng itdi dem-i iksâda fes (G95/5)

\section{Fes/Nev-heves}

Osmanlı Devleti için önemli bir yenilik olan ve o günün dünyasında Osmanlı Devleti’nde giyen giymeyen herkesi bir şekilde etkileyen fes, fitne çıkaran, yarin perçemini baştan çıkaran, cihanı fesada veren bir nev-hevese benzetilir. Nev-heves, lugatte, bir işe yeni ve büyük bir hevesle başlayan anlamına gelmektedir. Daha önce halkın tanımadığı fes o dönemde Osmanlı hayatında yenidir. Her yenilik gibi fes de önceleri halk arasında yadırganmış, toplumda bazı karışıklıklara sebep olmuştur. Aynî, top-

35 Ethem Cebecioğlu, Tasavvuf Terimleri ve Deyimleri Sözlüğü, Ankara: Rehber Yayınları, 1997, s.446. 36 Ferit Devellioğlu, Osmanlıca-Türkçe Ansiklopedik Lügat, Ankara: Aydın Kitabevi Yayınları, 1986, s.1041.

37 Türkiye'de Halk Ağzından Derleme Sözlüğü, haz., Türk Dil Kurumu, Ankara: TDK Yayınları, 1993, C.5, s.171.

38 Türkiye’de Halk Ağzından Derleme Sözlüğü, C.1, s.308. 
lumdaki kargaşayı 'fesad' kelimesiyle hissettirir. Aynı zamanda 'fes ve fesad' kelimeleri hem beyitin ahengini hem de verilmek istenen mesajı güçlendirmektedir:

Rüsûm-ı fitnede başdan çıkardı perçem-i yâri

Cihânı virmede reng-i fesâda nev-hevesdir fes (G96/3)

\section{Fes/Perçem}

Klasik Türk şiirinde fesle ilgili yazılan şiirlere bir bütün olarak bakıldığında fesin daha fazla perçemle birlikte kullanıldığı görülür. Bu durum Aynî Divanı'na da bu şekilde yansımıştır. Divanda fes ile perçem yedi yerde birlikte kullanılmıştır. Bilindiği üzere perçem, "bazen, bükümlü bazen örümlü, bazen dağınıktır" ${ }^{39}$ genellikle kıvrım kıvrım görüntüsüyle alna dökülen saçtır. Rengi siyahtır. Perçem, iki beyitte tıpkı bir kanat gibi fesin altından sağa ve sola döküldüğünden Hüma kuşuna ${ }^{40}$, büklüm büklüm görüntüsünden dolayı hazine bekçiliği yapan ejdere ${ }^{41}$, başka bir beyitte ise fesin güzelliği, hilesi karşısında baştan çıkan bir aşığa ${ }^{42}$, başka bir beyitte ise güzel kokusundan dolayı Çin ülkesine benzetilir:

Dîyâr-1 Çîn'e hükm eyler arak-çînindeki perçem

Ser-i uşşâka püskülli belâdır pek yamândır fes

\section{Fes/Peri}

Eserde fes, bir anda yüz bin hile yaparak zahidin beş vakit namazını bozan hilekâr bir peri olarak ele alınmıştır. 'Dem ve reng' kelimeleri aynı zamanda 'kan ve hile' anlamlarını çağrıştıracak şekilde tevriyeli kullanılmıştır. Böylece hem fesin kırmızı rengine hem de sosyal hayattaki etkisine gönderme yapılmıştır:

Ol peri bir demde yüz bin âdeme reng itdi kim

Zâhidin virdi salât-1 hamsesin ifsâda fes (G95/4)

\section{Fes/Püskül}

Fesin konu edildiği şiirlerde tıpkı perçem gibi püskül de çok tercih edilmiştir. "Fesin düz olan tepe kısmına "tabla" adı verilir ve bunun merkezindeki "ibik" denilen çıkıntıya lacivert veya siyah bir ipek püskül bağlanırdı." ${ }^{43}$ Püskül, fesin en önemli aksesuarıdı. Fese ve fesi kullanan kişiye göre değişiklik gösteren püskül, ilk zamanlarda fesin her tarafını saracak kadar büyükken sonraki zamanlarda boyutları küçülmüş ve fesin arka tarafında kalmıştır. ${ }^{44}$

Aynî, aşağıdaki beytin birinci mısrasında fesi yüceltmek için püskülü kullanmıştır. Şaire göre fesin püskülünün her bir telinde zafer nuru bağlıdır. İkinci beyitte ise şai-

39 Harun Tolasa, Ahmet Paşa’nın Şiir Dünyası, Ankara: Akçağ Yayınları, 2001, s.183.

40 Antepli Aynî Divanı, s.147,148.

41 Antepli Aynî Divanı, s.149.

42 Antepli Aynî Divani, s.147.

43 İslam Ansiklopedisi, "Fes” maddesi, s.416.

44Mehmet Zeki Pakalın, Osmanlı Tarih Deyimleri ve Terimleri Sözlüğü, İstanbul: Milli Eğitim Basımevi, 1983, s.613. 
rin devletin, gayr-i Müslimlerin de fes giymeleriyle ilgili reformundan pek memnun kalmadığı anlaşılmaktadır. Çünkü bu reformla birlikte Müslüman halkla Müslüman olmayan halk aynı konumda değerlendirilecek, iki kesimin arasındaki farkı gösteren önemli sembollerden birisi ortadan kalkacaktır:

Nûr-1 nusret bestedir her bir telinde püskülün

Olmasun kavm-i Yehûd u millet-i Tersâda fes (G95/6)

Aynîye göre ışığıyla gündüzü aydınlatan güneş aydınlığını festen almaktadır. Fes, yüksek âlemlerde güneşe 1şık verince gökyüzündeki ay, her gece fesin püskülünden dolayı tutulmaktan (ışı̆̆ını kaybetmekten) korkar:

Püskülünden her gicebîm-i husûfa düşdi mâh

Fer virince mihre gündüz âlem-i bâlâda fes (G97/4)

Fesin püskülünün kullanımı büyük sıkıntılara neden olmaktaydı. Önceleri bükülmemiş ipekten ya da gümüş tellerden yapılan bu püsküller, rüzgâr, yağmur gibi dış etkenlerden etkilenerek karmakarışık hale gelebilmekteydi. Çarşı pazarlarda başta Yahudi çocukları olmak üzere geçimini püskül taramaktan sağlayan bir zümre dahi türemişti. Fes tebaanın bir kısmı için "püsküllü bela” haline gelmişti. Bu duruma son vermek için 1845 yılında devlet görevlilerinin ve tebaanın örme püskül kullanmasına karar verildi. ${ }^{45}$ Fesin püskülü insanı fevkalade rahatsız ederdi. Sürekli taranıp, fırçalanıp düzeltilmesi gerektiğinden kullanılması başa bela olmuştu. Fese püsküllü bela denmesinin bir başka sebebi de; fes giymek istemeyenlere zorla giydirilmeye çalışılması, bununla ilgili baskı yapılmasıdır. 19. Yüzyılın Osmanlı içtimai hayatında kullanılan 'püsküllü bela' tabiri daha sonraları "Büyük sıkıntı, zarar veren kişi veya şey”"46 anlamında günümüze kadar gelmiş ve Türkçede aktif kullanılan bir deyim olarak sözlüklerde yerini almıştır:

Dîyâr-1 Çîn’e hükm eyler arak-çînindeki perçem

Ser-i uşşâka püskülli belâdır pek yamandır fes (G98/4)

\section{Fes/Renk}

Ressam, fırçası ile tabiattaki renkleri tablolaştırırken şair, kelimelerle duygularının manzaralarını çizer. İnsanın kullandığı renkler bilinç-altının ipuçlarını verir. Renkler duyguların ifade vasıtasıdır. ${ }^{47}$ Semboller dünyasının anahtarı gibi şairin anlatmak istediğini daha belirgin, daha etkili bir şekilde yansıtılmasını sağlar. Bazen toplumda yaşanan olaylarla olaylara sebep olan nesneler/objeler arasında bağ kurulur. Fes hadisesi buna güzel bir örnektir. Şairler; fesin kırmızı rengi ile fesin giyilmesi, giyilmek istenmemesi için dökülen kanlar arasında bağ kurarlar. Türk siyasi tarihinde önemli bir yere sahip olan fes, Türk kültür tarihinde de önemli bir yere sahiptir. Makalemizin giriş bölümünde de belirttiğimiz gibi tarih boyunca halk; kırmızı, narçiçeği,

45 Ahmed Lütfi Efendi, Vakínüvîs Ahmed Lütfi Efendi Tarihi, haz.. Yücel Demirel ve Tamer Erdoğan, İstanbul: Yap1 Kredi Yayınlar1, 1999, s.1201.

46 M. Ali Tanyeri, Örnekleriyle Türk Halk Şiirinde Deyimler, Ankara: Akçă̆ Yayınları, 1999, s.211.

47 Mahmut Kaplan, Osmanlı Şiirinde Aşkın Yedi Rengi- Elvân-ı Seb’a, (erişim 16.03.2019), https://www.publitory. com /e books/1069-askin-yedi-rengi-elvan-i-seb, s.3. 
vişneçürüğü, güvez, siyah, beyaz gibi. Değişik renklerde fesleri tercih etmiştir. Tabi bunlar arasında en yaygın kullanılan renk kırmızı ve kırmızının tonlarıdır. Aynî divanında, sadece kırmızının ve yakın tonlarının tercih edildiği görülmektedir. Mesela aşağıdaki iki beyitte şafak kızıllığı ve kırmızı fes arasında bağlantı kurulmuştur:

Gözlerim reng-i şafak-tâbından oldı hıyre-vâr

Gördügüm gün 'Ayniyâ ol âfitâb-âsâda fes (G95/7)

Fes, adeta seher vakti Hüda'nın nurundan yansıyan manevi bir tecellisi gibidir. Fes, nurunu güneşten ve aydan; rengini şafağın kızıllığından almaktadır:

Fürûg-1 mihr ü mehreng-i şafakdan muktebesdür fes

Seher vakti tecelli-i Hüdâdan mültemesdir fes (G96/1)

Aşağıdaki beytin tamamına kırmızı renk hakimdir. Beyitte, la'l ve akik taşı fesin kırmızı rengiyle tenasüp oluşturacak şekilde kullanılmıştır. Her iki taşın da rengi fes gibi kırmızıdır. Süheyl yıldızı ile hem akik hem la’l taşı arasında bağlantı vardır. "Süheyl, Yemen havalisinden başka yerde açıklıkla görünmeyen küçük bir yıldızdır. Ondan bahsedilirken, Yemen'de, çok olan la'lin meydana gelişinde tesiri olduğuna işaret edilir." ${ }^{48}$ Akik, için de benzer söyleyişler vardır. Akik taşına "Yemen taşı da denmiştir. İnanışa göre, rengini Süheyl yıldızının ışığının tesiriyle almıştır. Zira bu yıldızın en parlak görüldüğü yer Yemen'dir. ${ }^{49}$ Şaire göre; fes de akik ve la'l taşı gibi rengini Süheyl yıldızından almıştır. Sadece rengini almamıştır aynı zamanda ondan aldığı nurla öyle bir feyze mazhar olmuştur ki bu feyz sayesinde la’l ve akik taşının rengini paramparça edecek manevi bir güce sahip olmuştur:

Ne feyze mazhâr olmuş bak fer-i necm-i Süheylî̀den

Şikeste itmede reng-i akîk ü la’l-i besdir fes (G96/5)

Kızılbaş kelimesi klasik Türk şiirinde on altıncı yüzyıldan başlayarak son döneme kadar değişik anlamlarla kullanılan bir kelimedir. "Kızılbaş kavramı, Osmanlı-Safevî rekabetinden sonra ortaya çıkmış olan ve sadece bir kıyafet ismi olmanın ötesinde, başta dinî ve siyasî olmak üzere geniş bir çağrışım alanı kazanmıştır. Aslında kızıl keçe külah, göğü tutan al rengin sembolü olarak Türkmenlerin eskiden beri giymiş oldukları başlıktır. Safevî propagandaları sonucunda İran’a göç eden Türkmenlere karşılık Anadolu’da kalan kesim kızıl külah üzerine beyaz bir "Osmanlı mücevvizesi”" sarmış, İran’a gidip kızıl keçe külahlarıyla kalan Türkmenlere Kızılbaş denmiştir.” ${ }^{50}$ Bu kelime, edebiyatımızda son döneme kadar daha çok Osmanlı’nın karşısındaki güç olan Safevîler için kullanılırdı. Son dönemlerde yeniçerilerle ilgili kullanıldı̆̆ da görülür. Her halükarda Kızılbaş, Osmanlı karşısındaki rakip güç olarak karşımıza çıkar. Aynî, Osmanlı Devleti’ni temsil eden fesin karşısına, Kızılbaş mülkü ifadesiyle hem İran’ı hem de döneminde kanlı bir şekilde kaldırılan yeniçerilik müessesesini koyar:

48 Cemal Kurnaz, Hayalî Bey Divaninın Tahlili, Ankara: Kültür ve Turizm Bakanlığı Yayınları, 1987, s.439. 49 Mehmet Kırbıyık, "Bazı XVI. Yüzyıl Divanlarında Kıymetli Taşlar”, Selçuk Üniversitesi Fen-Edebiyat Fakültesi Dergisi, 62 (2007), s.62.

50 Reşat Genç, “Türk Düşüncesi, Davranışı ve Hayatında Renkler ve Sarı, Kırmızı, Yeşil”, Nevruz ve Renkler, haz., Sadık Tural ve Elmas Kılıç, Ankara: AKM Yayınları, 1996, s.43. 
Ne renge koydı bak âyîne-i dîdâr-ı cânânı

Bu sûretle Kızılbaş mülkine hayret-resândır fes (G98/3)

Fes'in rengiyle ilgili orijinal benzetmelerden birinde fes renkli kuş kafesine benzetilir:

Kimin başında devlet var ise matlûb ider 'Aynî

Hümâ-yı perçem-i dil-dâra rengîn âşiyândır fes (G98/7)

Divan şairleri, 'reng' kelimesini birden fazla anlamıla kullanarak kelime oyunu yaparlar. 'Reng' kelimesinin 'renk' dışında kullanılan diğer bir anlamı da 'hile’dir. Fes, kırmızı rengiyle sevgilinin güle benzeyen perçemini, hile yaparak baştan çıkarmıştır. Kırmızı kelimesinin eş anlamlısının "al” olduğu düşünülürse, hemen akla; 'al'ın eş seslisi 'âl' kelimesinin ikinci anlamı olan 'hile' akla gelir. Aynî, kelimelerin farklı anlamlarından istifade ederek görünen ve görünmeyen bağlantılarla fesle ilgili pek çok çağrışımı okuyucusuna ustaca aktarmıştır:

Çıkdı başdan perçemi sevdâlanup kâkül gibi

Ol güle bir hayli rengitdi dem-i iksâda fes (G95/5)

\section{Fes/Sâyebân}

Sâye-bân, lugatte; gölgelik, şemsiye, çadır anlamlarına gelir. Aynî, fesle ilgili olarak 'sâye-bân' kelimesinin çadır anlamını tercih etmiştir. Eserde fese benzetilen çadır, şafak rengindedir yani fes gibi kırmızıdır. Şaire göre fes, fes giyen sevgiliyi yine kendisinin cemalinin nurunun tecellisinden koruyan padişah çadırına benzer. Malum olduğu üzere "Otağ-ı hümayunların rengi kırmızıdır ve Osmanlı ordusunda padişahlar, şehzadeler, vezirler ve beylerbeylerinden başkası bu renkte çadır kullanmamıştır." ${ }^{51}$

Teb ü tâb-1 tecellî-i cemâl-i bâ-kemâlinden

O mâhı hıfz içün reng-i şafakdan sâyebân-dır fes (G98/5)

\section{Fes/Ser-ases}

Divandaki en orijinal benzetmelerin başında 'fes/ser-ases' benzetmesi gelir. Elimizdeki ilgili benzetmelere baktığımızda bu benzetmeye Aynî dışında başka bir şairde rastlanmamıştır. Aynî, dönemindeki pek çok şair gibi şiirinde geleneğin dışında yeni söyleyişlere yer vermiştir. Ser-ases benzetmesi bunun en güzel örneklerindendir. Asesler, günümüzdeki emniyet güçleri gibi o dönemde "asayişi sağlamakla görevlendirilmiş kişilerdi." ${ }^{2}$ Ser-ases de bugünkü emniyet müdürü gibi düşünülebilir. Fes, afet gibi güzel olan sevgilinin güzellik şehrini gamzenin ve gîsûnun yağmasından, hırsızlığından koruyan ser-ases olarak tasavvur edilmiştir:

O şehr-i hüsn-i âfetden fitenden hıfz içün her şeb

O düzd-i gamze vü gîsûya Âynî ser-asesdir fes (G96/7)

51 Kamile Akın ve Yusuf Keş, “Türk Kültüründeki Çadır Geleneğinin Osmanlı Minyatür Sanatına Yansımaları”, JIA Journal (IJIIA) Uluslararası Disiplinlerarası ve Kültürlerarası Sanat Dergisi, 2 (2017), s.113.

52 Ömer Özkan, Divan Şiirinin Penceresinden Osmanlı Toplum Hayatı, İstanbul: Kitabevi Yayınları, 2007, s.77. 


\section{Fes/Sûfî, Zâhid}

Sûfî ve zahid, fesi kabul etmeyen kaba softalar olarak ele alınır. Eserde, fes giyenler idealize edilirken fes giymeyen sûfiler yerilir. Hatta onlara "Allah kavuklarını taş eylesin.” diye beddua edilir. Şaire göre yeniliğe kapalı olan bu kişiler ölü gönüllü kişilerdir. Bunlar Firavun'a benzer, nefisleri de ejdere:

Sûfi-i dil-mürdenin Hak kavugun taş eylesin

Geymemiş rûz-1 ibâdetde şeb-i ihyâda fes (G97/6)

Sûfîyi Fir’avn ider nefs-i habîsin ejdehâ

Berk urup nûr-1 tecellî dilberim Musâ’ da fes (G95/3)

\section{Fes/Tâc}

Rüyada görülen fes, mana aleminde tac ile yani rüyayı gören kişinin kavuşacağı makam-mansıp ile tabir olunur:

Geydi gördüm meh-cebînim bu gece rüyâda fes

Şâh-1 hüsne tâc ile ta'bîr olur ma’nâda fes (G97/1)

\section{Feshâne}

Divanında 522 tarih manzumesi ile döneminde gerçekleşen önemli hadiselerin çoğuna tarih düşüren Aynî, fes üretiminin yapıldığı Feshane’nin açılmasıyla ilgili üç, fes imalatında Feshane’ye gelmeden önce feslerin hazırlanıp yıkandığı İznikmîd (İzmit) Dinkhâne'si ile ilgili bir tarih düşürmüştür. Farsça 'dink' ve 'hâne' kelimelerinden oluşan 'dink-hâne' ibaresi keçe dövülerek fes yapılan îmâlathâne yani feshane anlamında kullanılmaktadır.

Feshâne "II. Mahmud tarafından askeriyenin ve halkın fes ihtiyacını karşılamak üzere kurulmuştur. Yeniçeri Ocağı’nın kaldırılmasından sonra teşkil edilen Asakir-i Mansûre-i Muhammediyye ordusunun kıyafeti belirlenirken başlik olarak fesin kabul edilmesi zamanla bu başlığın halk arasında da yaygınlaşmasına yol açtı. Artan fes talebi önceleri Tunus ve Misır'dan, daha sonra da Avrupa'dan ithal edilerek karşılanmaya çalışıldı." ${ }^{33}$ İlerleyen zamanlarda talep arttıkça Tunus ve Mısır'dan sonra Avusturya ve Fransa'dan getirilen feslerin maliyeti devlete ciddi yük olmaya başlaması üzerine "feslerin yurt içinde üretilmesi için teşebbüse geçildi ve bu gibi konularda bilgisi bulunan Kâtibzade Mustafa Efendi fes nazırı tayin edildi. Mustafa Efendi ilk iş olarak Tunus 'tan İstanbul'a yirmi üç fes ustası, yanlarında çalıştırılmak üzere Bursa'dan da on beş kabiliyetli kalfa getirtti ve mukataat hazinesinden tahsis edilen 1.5 milyon kuruş ile 1833'te Kadırga’daki Cündî Meydanı'nda bulunan hazine-i hassaya ait bir binada fes üretimini başlattı. Ayrıca feslerin yıkanma işlemlerinin gerçekleştirilmesi amaciyla İzmit’te de bir dinkhane kuruldu. ${ }^{54}$

Aynî Divanı’nda İzmit’teki dink-hânenin kurulmasıyla ilgili bir tarih düşürülmüştür.

53 İslam Ansiklopedisi, Tevfik Güran, İstanbul: Türkiye Diyanet Vakfı Yayınları, 1995, "Feshâne” maddesi,s.426. 54 İslam Ansiklopedisi, "Feshâne” maddesi, s.426. 
Bu tarih divanın 'Tarihler’ bölümünde 'İznikmîd’de Îcâd Olunan Dînk-hâneye’ başl1ğıyla kaleme alınmıştır. Aynîye göre dink-hânenin kuruluş tarihi H.1249'dur:

Mahmûd Hân'a sâpâş cünd-i sürûşa sır-daş

Devrinde cümle evbâş itdi penâh suyın (T236/1)

Yapdırdı dînk-hâne geydürdi fes cihâna

Bildürdi ins ü câna tedbîr-i feyz-i cûyın (T236/2)

Târîhe 'Ayniyâ bes koysun baş üzre herkes

"Bak dînk-hâne-i fes yapıldı buldı suyın" (T236/3) (1249)

"Kadırgadaki atölye zamanla yetersiz gelmeye başlayınca, Eyüp’te Defterdar semtinde münhasıran fes fabrikası inşa edilmesine karar verildi. Buradaki Beyhan Sultan Sarayı birtakım inşaatla Feshane’ye dönüştürüldü. II. Mahmud'un iradesiyle 1833 Nisanının sonlarında Kadırga'daki tesisler buraya taşındı. Birkaç yıl sonra mekân yetersiz kalınca, çevredeki bazı yapılar istimlâk edilerek Feshane genişletildi." ${ }^{55}$

Aynî, divanındaki 267 No’lu 'Ahd-i Hâkân-1 Firdevs-Âşiyân-1 Müşârün-İleyhde Îcâd Olunan Feshâneye Târîhdir' başlıklı tarih manzumesi, Feshane’nin Beyhan Sultan Sarayı'na taşınması yeniden kurulması ile ilgilidir. Şair yedi beyitten müteşekkil olan tarihin ilk beş beytinde padişaha medh ü senada bulunur. Altıncı beyit olan mahlas beyitte Fes-hane ile ilgili düşürdüğü iki tarih manzumesi ile övünür. Düşürdüğü tarihlerin, padişah tarafından da beğenildiğini, bu sebeple söz konusu tarihlere 'tâc-1 mücevher' dense seza olacağını ifade eder. Feshâne’nin H. 1252 yılında ümmetin padişahı olan II. Mahmud tarafından kurulduğunu, söyler:

Ayniyâ oldu huzûr-1 pâdişâhîde pesend

Bu iki târihime tâc-1 mücevher dense bes

“İtdi fes-hâne binâ Sultân Mahmûdü’l-ümem” (1252)

"Yapılup iclâl ile fes-hâne çıkdı başa fes" (T267/7) ${ }^{56}$

Feshane’nin inşası ile ilgili diğer tarih manzumesi 'Tarihler' bölümündeki 268 nolu beş beyitlik tarih manzumesidir:

Târîhin inşâd eyledi 'Aynî dilin şâd eyledi

"Fes-hâne bünyâd eyledi Sul冈ân Mahmûd-ı hümâm” (1252) (T268)

\section{Fesle İlgili Benzetmeler}

\begin{tabular}{|l|c|}
\hline Fes-Renk & 10 \\
\hline Fes-Işs/k/Nûr & 9 \\
\hline Fes-Perçem & 7 \\
\hline Fes-Çiçek & 4 \\
\hline
\end{tabular}

55 Ahmet Yaramış, "Feshane’nin İlk Kuruluş Yılları", Tarihi, Kültürü ve Sanatıyla VIII. Eyüpsultan Sempozyumu:Tebliğler, (7-9 Mayıs 2004), s.98.

56 Antepli Aynî Divanı, s.235. 


\begin{tabular}{|l|l|}
\hline Fes-hâne & 4 \\
\hline Fes-Asker & 3 \\
\hline Fes-Püskül & 3 \\
\hline Fes-Sûfî/Zâhid & 3 \\
\hline Fes-Nevheves/Nevcivân & 2 \\
\hline Sade Fes & 1 \\
\hline Fes-Âşiyân & 1 \\
\hline Fes-Hazine & 1 \\
\hline Fes-Kafes & 1 \\
\hline Fes-Kâkül & 1 \\
\hline Fes-Peri & 1 \\
\hline Fes-Sâyebân & 1 \\
\hline Fes-Ser-ases & 1 \\
\hline Fes-Tâc & 1 \\
\hline
\end{tabular}

Antepli Aynî Divanı'nda fesle ilgili olarak; renk (10), 1şık/nûr (9) perçem (7) çiçek (4) asker, sûfî/zâhid ve püskül (3), nevheves/nevcivân (2), âşiyân, hazine, kafes, kâkül, peri, sâyebân, ser-ases (1) benzetme yapılmıştır. Bu sonuçlara göre şair, fesi en fazla renk unsuruyla birlikte ele almıştır. Kullandığı renk, ağırlıklı olarak -o dönemdeki fesin rengi olan- kırmızıdır. Kırmızıyı hemen ardından asker kıyafetlerinde tercih edilen yeşil renk takip eder. 'Fes-1şık/nûr' ile ilgili benzetmelerde şair fese ulvî bir mana yüklemiş, mübalağalı söyleyişlerle fesi adeta kutsamıştır. Üçüncü benzetme yedi defa tercih edilen 'Fes-perçem' benzetmesidir. Fes ile perçem son döneme kadar her dönemde şairlerin tercih ettiği alışılmış bir benzetmedir. Çiçek, kâkül, püskül de böyledir. Bu benzetmelerin dişında; gelenekte kullanılan teşbihlerden tamamen farklı olarak sadece Aynî Divanı'nda görülen benzetmeler bulunmaktadır. Bunlar; 'âşiyân, hazine, kafes, nevheves/nevcivân, sâyebân, ser-ases, peri' benzetmeleridir. Aynî, farklı benzetmeler kullanarak hem savunmak istediği 'fes' konusuna dikkat çekmiş hem de döneminin bir özelliği olarak şiirde yeni kullanışlara yer vermiştir.

\section{Sonuç}

Fes, Klasik Türk şiirine her ne kadar daha önce girmiş olsa da onun divanlarda farklı yönleriyle işlenişi II. Mahmud döneminden sonra olmuştur. Dönemin padişahının yaptığ karşılanmış olmasına rağmen zamanla kadın-erkek, Müslüman-gayr-i Müslim geniş kitleler tarafından kabul görmüş, 1925’te yasaklanıncaya kadar farklı çeşitleri ve renkleriyle sosyal hayat içinde önemli bir yere sahip olmuştur. Yeniçeriliğin kaldırılmasından sonra yapılan reformlarla ordunun kıyafetleri tamamen değiştirilmiş, değişen kıyafetler arasında üzerinde en çok tartışılan unsur fes olmuştur. Fes meselesi toplumu o kadar etkilemiştir ki fesle ilgili konular sadece siyasetçilerin değil sanat camiasının da gündemine girmiştir. Gerek divan şiirinde gerek halk şiirinde pek çok şair fes reformunun propagandasını yapan gazeller yazmış, tarihler düşürmüş, desteklerinden dolayı padişah tarafından ödüllendirilmiştir. II. Mahmud döne- 
mi şairlerinden Antepli Aynî, fes konusunda kaleme aldığı şiirleriyle, konuyla ilgili orijinal benzetmeleriyle ve değerlendirmeleriyle muasırları arasında müstesna bir yere sahiptir. Birinci sınıf bir şair olmamasına rağmen padişahın icraatlarını desteklediği için II. Mahmud tarafından Osmanlı Devleti’nin ilk silahşörlük payesi olan bir mücevher nişân ile taltif edilerek "Mümeyyizü’ş-Şu’arâ” (seçkin şair) olarak tayin edilmiştir. Aynî, divanında, her biri yedi beyitten oluşan fes redifli dört gazel yazmış bunun yanında Feshâne'nin kuruluşu ile ilgili dört tarih düşürmüştür. Eserde, fesle ilgili hangi benzetmelerin kullanıldığı ve kaç defa geçtiği aşağıdaki tabloda gösterilmiştir.

Fes, Osmanlı toplumunda kabul gördükten sonra pek çok çeşidiyle karşımıza çıkar. Aynî Divanı'nda yalnızca; o dönemde sivillerden ayrılmaları için resmi görevlilerin giydiği 'sade fes' geçer. Düşürdüğü tarihlerle döneminde meşhur olan Aynî, Feshâne’nin kuruluşu ile ilgili dört tarih düşürmüş̧ür. Fes, beyitlerin hemen hemen tamamında olumlu olarak ele alınmış, bazı beyitlerde fesi kabul etmeyenler, karşı çıkanlar eleştirilmiştir. Şair, bir beyitte, gayr-i Müslimlerin fes giymelerinden çok hoşnut olmadığını ince bir şekilde hissettirmiştir. Bir yerde ise layık olan olmayan herkesin fes giydiğinden şikâyet eder. Hal böyle olunca toplumda iyi ile kötü birbirine karışmıştır.

Aynî, fesle ilgili değerlendirmeleriyle Osmanlı Devleti’nin son döneminde gündemi fazlasıyla meşgul eden önemli bir konuya ışık tutmakta, bu hadiseyle ilgili önemli ipuçları vermektedir. Toplumu derinden etkilemiş olan fes reformuna şairler duyarlı davranmış edebiyatımızda çok sayıda fes şiiri kaleme alınmıştır. Fes konusu edebiyatımızda, tarihiyle, -cinsiyet, kesim, etnik gruba göre- çeşitleriyle, yapıllışının sanata yansımasıyla, klasik Türk edebiyatı ve halk edebiyatındaki metinlerin karşılaştırılmasıyla, dilimize kazandırdığı deyim, atasözü, söyleyiş ve benzetmeleriyle üzerinde geniş ve kapsamlı araştırmalar yapılması gereken çok boyutlu bir konudur. Aynî Divanı, bu konuyla ilgili edebiyat, siyaset ve kültür tarihi vb. gibi pek çok alanda yapılacak akademik çalışmalara kaynaklık etmesi bakımından mutlaka başvurulması gereken önemli bir kaynaktır.

\section{Kaynakça}

Ahmed Lütfi Efendi. Vakanüvîs Ahmed Lütfi Efendi Tarihi, II-III. Haz Yücel Demirel ve Tamer Erdoğan. İstanbul: Yapı Kredi Yayınları, 1999.

Ahmet Rasim. Osmanlı Tarihi ( Seçmeler ). Haz. İsmet Parmaksızoğlu. İstanbul: MEB Yayınları, 1994.

Akın, Kamile ve Yusuf Keş. “Türk Kültüründeki Çadır Geleneğinin Osmanlı Minyatür Sanatına Yansımaları”.JIA Journal (IJIIA) Uluslararası Disiplinler arası ve Kültürlerarası Sanat Dergisi. 2 (2017):113-128.

Antepli Aynî Divanı. Haz. Mehmet Arslan.İstanbul: Kitabevi Yayınları, 2004.

Barbarosoğlu, Fatma K. Moda ve Zihniyet. İstanbul: İz Yayıncılık, 2004.

Caferoğlu, Ahmet. “Türk Onomastiğinda Başlık Yahut Serpûş”, Sekizinci Türk Dil Kurultayı Bildirileri, http://katalogtarama.cekulvakfi.org.tr/resimler/3/4/1430/ ab00000062.pdf, (erişim 16.03.2019). 
Cebecioğlu Ethem. Tasavvuf Terimleri ve Deyimleri Sözlüğü. Ankara: Rehber Yayınlar1,1997.

Çakır, Hamza. “Türkçe Basında İlk “Marka” Rekabeti”.Erciyes Üniversitesi Sosyal Bilimler Enstitüsü Dergisi. 1/16 (2004): 27-36.

Çiftçi, Ömer. Hatimetü’l-Eşầr (Fatin Tezkiresi, http://ekitap.kulturturizm.gov.tr/ Eklenti/55976, fatin-tezkiresi- pdf. pdf?0, s. 319-370. (erişim:06.02.2019).

Daştan, Nihangül. “Türk Halk Şiirinde Bir Propaganda Aracı Olarak Fes Şiirleri”. Akademi Sosyal Bilimler Dergisi. 5/15 (2018): 47-48.

Devellioğlu, Ferit. Osmanlıca-Türkçe Ansiklopedik Lugat. Ankara: Aydın Kitabevi Yayınları, 1986.

Demirel, Şener. “Antepli Aynî Divanı’ndaki Tarih Manzumeleri Üzerine Bir İnceleme”. Turkish Studies, International Periodical Forthe Languages, Literature and History of Turkishor Turkic. 3/4 (2008): 372-398.

Demirtaş, Hasan. "Arşiv Belgeleri Işı̆ğında Şeyh Meknun (Bektut)/Açıkbaş Zaviyesi ve Türbesi https://docplayer.biz.tr /53587617-Tokat-tarihi-ve-kulturusempozyumu.html, s.485-499, (erişim 16.03.2019).

Durmaz, Gülay. "Püsküllü Bela: Diyarbakırlı Osman Nûrî Paşa Divanı’nda Fes”. Uludă̆ Üniversitesi Fen-Edebiyat Fakültesi Sosyal Bilimler Dergisi. 15/26 (2014): 201-213.

Genç, Reşat. “Türk Düşüncesi, Davranışı ve Hayatında Renkler ve Sarı, Kırmızı, Yeşil”, Nevruz ve Renkler. Haz. Sadık Tural ve Elmas Kılıç. Ankara: AKM Yayınları, 1996, s.41-48.

İnce, Yunus. “II. Mahmut Dönemi Reformlarının Tebaa Tarafından Algılanışı”.Tarih Íncelemeleri Dergisi. XXXII/2 (2017): s.427-457.

İslam Ansiklopedisi. Halil İnalcık. 19. cilt. İstanbul: Türkiye Diyanet Vakfı Yayınları, 2002.

İslam Ansiklopedisi. Hülya Tezcan. 12. cilt. İstanbul: Türkiye Diyanet Vakfı Yayınları,1995.

İslam Ansiklopedisi. İsmail Ünver. 4. cilt. İstanbul: Türkiye Diyanet Vakfı Yayınları, 1991.

İslam Ansiklopedisi. Tevfik Güran. 12. cilt. İstanbul: Türkiye Diyanet Vakfı Yayınları, 2002.

Kaplan, Mahmut. Osmanlı Şiirinde Aşkın Yedi Rengi- Elvân-ı Sebả, https://www. publitory.com/e_books/1069-askin-yedi-rengi-elvan-i-seb, (erişim6.03.2019)

Kılıç, Selami. "Şapka Meselesi ve Kılık Kıyafet İnkılâbı”. Atatürk Yolu. 16/4 (1995): 529-547.

Kırpık, Cevdet. "Osmanlı İmparatorluğu’nda Modernleşme Sancıları, Fes-Şapka Çatışması”. Toplumsal Tarih. 162 (2007): 14-22.

Koca, Emine. “18.ve 19. Yüzyıl Osmanlı Erkek Modası”. Türk İslam Medeniyeti Akademik Araştırmalar Dergisi. 7 (2009): 63-82. 
Koca, Emine. "Osmanlıda Yapılan Kılık Kıyafete İlişkin Reformların Erkek Giysilerinin Biçimsel Özelliklerine Etkileri”. 20th CIÉPO Symposium New Trends in Ottoman Studies. (2012 Haziran): 971-995. (erişim 16.03.2019).

Koçu, Reşat Ekrem. Türk Giyim Kuşam ve Süslenme Sözlüğü. Ankara: Sümerbank Kültür Yayınları, 1969.

Kırbıyık, Mehmet. “Bazı XVI. Yüzyıl Divanlarında Kıymetli Taşlar”. Selçuk Üniversitesi Fen-Edebiyat Fakültesi Dergisi. 62 (2007): 61-75.

Kurnaz, Cemal. Hayalî Bey Divaninın Tahlili. Ankara: Kültür Bakanlığı Yayınları, 1987.

Mengi, Mine. "Fes ya da Püsküllü Bela ve Şiir”, Prof. Dr. Mehmet Özmen Armă̆anı. (2014): 230-238.

Nedîm Divanı. Haz. Muhsin Macit.Ankara: Akçă̆ Yayınları, 1997.

Ograş, Rıza. Es’ad Efendi ve Bağçe-i Safâ-Endîz’u, http://ekitap.kulturturizm.gov. tr/Eklenti/59393,esad-mehmed-efendi-bagce-i-safaenduzpdf. pdf?0, (erişim 06.02.2019).

Onay, Ahmet Talat. Türk Edebiyatında Mazmunlar. Haz. Cemal Kurnaz, Ankara: Akçă̆ Yayınları, 1993.

Özcan, Abdülkadir.“II. Mahmut ve Reformları Hakkında Bazı Gözlemler”. Tarih Incelemeleri Dergisi. 10 (1995): 13-39.

Özcan, Hüseyin. “Türk Halk Şiirinde Sosyal Hayat Bağlamında Aşık Dertli’nin Fes Redifli Şiiri”.Uluslararası Sosyal Araştırmalar Dergisi. 7/33 (2014): 234-239.

Özdemir, Fatih.“Kızıl Elma’yı Arayan Üç Yazar: Ömer Seyfettin, Ziya Gökalp, Ragıp Şevki Yeşim”. Turkish Studies International Periodical For The Languages, Literature And History Of Turkish Or Turkic. 3/5,503 (2008): 503-515.

Özkan, Ömer. Divan Şiirinin Penceresinden Osmanlı Toplum Hayatı. İstanbul: Kitabevi Yayınları, 2007.

Öztoprak, Nihat. "Divan Şiirinde Giyim Kuşam Üzerine Bir Deneme”. Divan Edebiyatı Araştırmaları Dergisi. 4 (2010): 103-154.

Pakalın, Mehmet Zeki. Osmanlı Tarih Deyimleri ve Terimleri Sözlüğ̈̈, İstanbul: Milli Eğitim Basımevi, 1983.

Sezer, Hamiyet. "Yeniçeri Ocağı’nın Kaldırılışının Taşraya Yansıması 1826-1827”. Ankara Üniversitesi Dil ve Tarih-Coğrafya Fakültesi Tarih Bölümü Tarih Araştırmaları Dergisi.19/30 (1997): 215-238.

Sipahi ve Çetin. "1697-1910 Yılları Arasında Osmanlı Kültüründe Muhasebecilerin Mezar Taşlarının KarakteristikÖzellikleri”, Muhasebe Finansman Akademisyenleri Dergisi, 48 (2010), s. 232-241.

Şeyh Gâlîb Dîvânı. Haz. Muhsin Kalkışım. Ankara: Akçağ Yayınlan, 1994.

Tanyeri, M.Ali. Örnekleriyle Türk Halk Şiirinde Deyimler. Ankara: Akçağ Yayınları, 1999.

Tolasa, Harun. Ahmet Paşa’nın Şiir Dünyası. Ankara: Akçă̆ Yayınları, 2001. 
Tulum, Mertol. 17. Yüzyıl Türkçesi ve Söz Varlı̆̆ı. Ankara: Türk Dil Kurumu Yayınları, 2011.

Turan, Şerafettin. Türk Kültür Tarihi, İstanbul: Bilgi Yayınevi, 1994.

Türkiye’de Halk Ağzından Derleme Sözlüğü. Haz. Türk Dil Kurumu. Ankara: TDK Yayınlar1, 1993.

Yaramış, Ahmet. "Feshane’nin İlk Kuruluş Yılları”. Tarihi, Kültürü ve Sanatıyla VIII. Eyüpsultan Sempozyumu: Tebliğler, (7-9 Mayıs 2004): 94-99.

Yaramış, Ahmet. "Osmanlı Ordusunda Çocuk Askerler Meselesi (Talimhane-i Sıbyan)”. Afyon Kocatepe Üniversitesi, Sosyal Bilimler Dergisi. 8 (2006): 53-62. 


\title{
Antepli Ayni's Poems in the Context of Reflection of Turkish Socio-Cultural Life
}

\author{
NURGÜL ÖZCAN
}

\begin{abstract}
Abstract: The fez, known as a symbol of the Ottoman's nowadays, has an ancient history. Turks met the fez in the 16th century by way of the Algerian sailors. It's official acceptance come across the period of the Mahmud II, with the disbandment of the corps of janissaries. The fez was brought to the Ottoman life by seraskier Hüsrev Pasha. After that, with Mahmud II's request it became the periods' official headwear. But nevertheless, the acceptance of the fez by the society was not that easy. There with the fez was not only the topic of the politicians, but also became the topic of the artists. The poets wrote poems to make the fez propaganda. Aynî from Antep, was one of the poets of this period, honored with compliments by the sultan, because of his supportive praises and chronograms about the fez reform. This work contains the elements related to the fez in Aynî's divan and deals with the poet's approach to the fez problem in detail. Also this study reflects the poet's perspective on the fez reform that had an impact on Ottoman social life of this time and how he transferred this subject to the literature.
\end{abstract}

Keywords: Fez, Feshane, Mahmud II, Aynî. 